\title{
Local Bureaucratic Governance and Discretion of Street Level Bureaucracy in Implementation of Food Diversification Policy in Indonesia
}

\author{
Alwi ${ }^{1, a)}$, Didik Iskandar ${ }^{2}$, Muh. Firyal Akbar ${ }^{3}$ \\ ${ }^{I}$ Department of Administration Science, Hasanuddin University \\ Address: Jl. PerintisKemerdekaan KM.10, Tamalanrea, Kota Makassar 90245, South Sulawesi Province, Indonesia (E- \\ mail: alwifisip@gmail.com ) \\ ${ }^{2}$ Departemen Of Public Administration Science, STISIP Veteran Palopo \\ Address: Jl. Diponegoro No. 33 Palopo City 90921, South Sulawesi, Indonesia \\ ${ }^{3}$ Departement of Administration Science, Muhammadiyah University of Gorontalo \\ Address: Jl. Prof. H.Mansoer Pateda, Gorontalo 96212, Indonesia (Email : firyalakbar@umgo.ac.id)
}

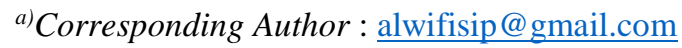

\begin{abstract}
Local bureaucratic governance is the implementer of a policy that has a rigid and measurable system. Such a system will be a dilemma faced by street-level bureaucracy when it is faced with the target group of a policy. To avoid this dilemma situation, this institution needs to have a pattern of perceptions, rules, and patterns of interaction, as mentioned in the institutional network theory. The main objective of this study is to explain the perceptions, rules, and patterns of interaction of stakeholders in the food diversification policy implementation network. The methodological approach used in this research is qualitative. The research strategy used is a case study with an explanatory type to explain the phenomenon in the implementation of food diversification policies based on the context in Bone Regency. Then, the analytical technique used is the pattern matching technique, in which the pattern is used is a theoretical pattern, namely the institutional network theory. Based on the research results, the implementation of the food diversification policy has not been effective. This is due to the pattern of perceptions among stakeholders, especially local bureaucracy and street-level bureaucracy which are still dominated by mindset oriented funds. Rules are not designed together so that they have not become binding for all stakeholders to improve the performance of this policy. Then, the pattern of interaction between stakeholders is still dominated by local bureaucracy so that street-level bureaucracy still uses command and control procedures against citizens as the target group of this policy. Therefore, it is necessary to build synergy and togetherness so that he can exercise discretion in the implementation of food diversification policies.
\end{abstract}

Keywords: Local bureaucratic governance, discretion, street-level bureaucracy, policy implementation, and food diversification. 


\section{INTRODUCTION}

To improve the performance of the public policy, the local collaborative institution becomes important because in addition to being part of the policy implementer it is also an institution that can bind all stakeholders [1]. Then concept of local bureaucratic governance is the implementer of a policy that has a rigid and measurable system. In carrying out its duties, the bureaucracy works to prioritize command-andcontrol procedures, narrow work restrictions, and inward-looking culture and operational models [2]. A system like this encourages the bureaucracy to work more on applying rules than achieving goals. This makes it difficult for him to adapt to unpredictable environmental changes, including the implementation of policies involving multi-actors [3]

The Command system and strict application of rules in the implementation of a policy is a dilemma faced by street-level bureaucracy when it is faced with the target group of a policy. The same is true when input resources are limited so that they are unable to meet the demands of citizens as the target group. In this case, it is always faced with a work environment that is not conducive to meeting these demands. This condition requires discretion for this [4].

Discretion will be important for street-level bureaucracy so that policy implementation can be effective. It is at the front level, - a level that determines the success of implementing a policy. Therefore, institutional strengthening is important so that it does not get into a dilemma between orders from superiors and demands from citizens as the target group for a policy. To avoid this dilemma situation, this institution needs to have a pattern of perceptions, rules, and patterns of interaction, as stated in the institutional network theory [5]. There are several institutional perspectives that explain the order and legitimacy of an organization, namely sociological, political, and economic perspectives [6]. However, the institutional perspective used here is the sociological perspective, namely: institutional network theory which is a powerful theory explaining the phenomenon of local bureaucratic governance.

Perception patterns mean that actors act based on their perceptions, which contain an understanding of existing content which often experiences differences with other actors where a common understanding of perceptions can be created through the experiences and interactions of actors with one another. Furthermore, rules in the network arise during interactions in either formal situations (made and decided consciously) or informal (produced casually during an interaction, without being made explicit), and also rules are defined as fixed and generalizable interaction procedures that can provide an anchor to actors. in relation to questions such as who is included in the network, the role of each actor, the identity of the different actors. Meanwhile, interaction patterns can be assessed in various ways, such as considering the intensity of the interaction and determining which actors are most closely related to one another [7]. Looking at the diversity of interactions will provide a better understanding of how many actors interact with each other, the intensity and variety of interactions provide information about which actors are central and which are around the network. They also show how easily actors communicate with other actors [5].

One of the policies that determine the lives of Indonesian citizens is the policy of food diversification. This policy is a top-down approach that demands local bureaucratic governance as the implementer. Food diversification is an effort to encourage people to diversify their staple foods so that they do not focus on just one type. Law Number 18 of 2012 concerning Food mandates that food administration is carried out to meet basic human needs that provide fair, equitable, and sustainable benefits based on food sovereignty, food self-sufficiency, and food security. In accordance with its duties and functions, the Food Security Agency implements the Community Food Diversification and Security Improvement Program, covering 4 (four) main activities, namely: (1) Development of Food Availability and Management of Food Insecurity; (2) Development of Food Price Stability and Distribution System; (3) Development of Food Consumption Diversification and Improvement of Fresh Food Safety; (4) Management and Other Technical Support at BKP (Kementrian Pertanian Indonesia, 2019).

The main objective of this policy is to seek food diversification as one of the programs to increase national food availability that focuses on certain local food commodities as well as the massive use of local food. However, based on BPS data (detikfinance.com, accessed January 4, 2017), Indonesia imported 14473 tons of rice and this shows that in the same period in 2016 it only imported 2000 tons. This is in line with the study conducted by [9], [10] and [11] that the implementation of food diversification policies in Bone Regency is one of the granary areas. national food has not been effective. Therefore, this study focuses on the perception patterns, rules, and interaction patterns of stakeholders in the food diversification policy implementation network.

\section{PROBLEM STATEMENT}

According to the Central Statistics Agency (BPS) in 2017, our per capita rice consumption rate shows a very high number. Indonesia's rice consumption is $114.6 \mathrm{~kg}$ per capita per year, far above the consumption of world rice consumers, which averages only $60 \mathrm{~kg}$ per capita 
per year. Currently, the majority of people consume rice, even though there are 100 types of carbohydrate foods, from potatoes, cassava, sago, wheat, and others. Indonesia is still lagging behind in the problem of food diversification when compared to other countries such as Korea (40 kg per capita per year), Japan (50 kg per capita per year), Malaysia (80 kg per capita per year), or Thailand (70 kg per capita per year.). Therefore, it needs a discretion mechanism in local bureaucratic governance to synergize all stakeholders in the implementation of food diversification policy.

Based on the introduction and problem statement above, the research question posed is how the pattern of perceptions, rules, and interaction patterns in local bureaucratic governance to exercise discretion in the implementation of food diversification policies in Bone Regency, Indonesia. Purpose of Study are to explain the pattern of perceptions, rules, and patterns of interaction in local bureaucratic governance to exercise discretion in the implementation of food diversification policies in Bone Regency, Indonesia.

\section{METHOD}

The food diversification policy is a top-down approach, where the content of this policy is the same which is applied in different contexts throughout Indonesia. Bone Regency is a national food storage area, but it is on the order of 166 with a score of 77.17 out of 412 districts in Indonesia. The research design used in this research is qualitative research, to reveal and explain the mechanism of discretionary local bureaucracy governance in the implementation of food security policies in Indonesia. Then, the research strategy used is a case study with an explanatory type [12], to explain the discretionary mechanism in local bureaucratic governance in implementing food diversification policies based on the context. The informants in this study were as follows: a) Food Security Agency; b) Agriculture Agency; c) Chair and members of the Women Farmers Group b). sub-district extension team; d) District extension team. This study uses data collection techniques including observation, in-depth interviews, and documentation. The data processing technique used is data reduction through data categorization and classification. Then, the pattern matching analysis technique in which this pattern is based on a theoretical pattern, namely the pattern of perceptions, rules, and interaction patterns in local bureaucratic governance is a discretionary mechanism determining the successful implementation of food diversification policies.

\section{RESULT AND DISCUSSION}

\subsection{Perception Pattern of Street-Level Bureaucracy in the Implementation of Food Diversification Policy in Bone Regency}

Perception patterns mean that actors act based on their perceptions, which contains an understanding of existing content that often experiences differences with other actors where a common understanding of perceptions can be created through the experiences and interactions of actors with one another. This study shows that the pattern of perceptions between the Food Security Service and the Agriculture Service on food diversification policies is different. This is shown in the handling of food diversification where the two agencies have their respective programs on this matter. These two offices as street-level bureaucracy aim to achieve food security, however, the Agriculture Office only focuses more on increasing food production. Meanwhile, the Food Security Service focuses on food availability, accessibility, and consumption. This difference in perception results in the absence of an agreed collaborative program and collective action in overcoming food problems. Food diversification policy is a national policy that aims to sustain and improve nutrition through local food. As a policy, this two streetlevel bureaucracy should have the same perception so that food and nutrition problems in the community can be solved together. The female farmer group (KWT) is the target group for the food diversification policy, only the Food Security Office fosters it both in support of resources and strengthening of its institutions. However, the Department of Agriculture did not make KWT a target group in this policy. This shows that different perceptual patterns make it difficult for them to exercise discretion to improve the performance of food diversification based on local food.

\subsection{Rules of the Implementation of Food Diversification Policy in Bone Regency}

Rules in policy networks arise during interactions in either formal situations (made and decided consciously) or informal (produced casually during interactions, without being made explicit) and also rules are defined as fixed and generalizable interaction procedures that can provide an anchor to actors in related to questions such as who is included in the network, the role of each actor, the identity of different actors. This research shows that the rules formed in the interaction between actors are formal rules that have been designed topdown. Providing assistance to farmers if they have a group called the Women's Farmers Group (KWT). To get this assistance must go through a mechanism or requirements, such as a proposal submitted to the Food 
Security Service. KWT is accompanied by agricultural extension workers who are part of this policy scheme. KWT assistance is a form of interaction between streetlevel bureaucracy and its target group. Interaction is always based on bureaucratic rules that govern technically the implementation of food diversification policies. The implementers of this policy have not yet exercised discretion in the midst of strict bureaucratic rules, so they have not yet achieved the goal of this policy, a pattern of balanced food consumption based on local food. Until now, the food consumption pattern has not shifted significantly to local food consumption. It still applies "they are not full if they don't eat rice" for most people. In this case, Indonesia occupies the highest position in rice consumption compared to other ASEAN countries. In 2017, Indonesia consumed $114.6 \mathrm{~kg}$ of rice per capita per year and in 2019 , it consumed $111.58 \mathrm{~kg}$ per capita per year. This shows that the implementation of this policy does not make a significant contribution to solving the food problem. Based on this, they do not yet have the ability to get out of bureaucratic rules and design a bureaucratic governance mechanism that supports discretion for the bureaucracy who is directly facing the target group of a policy.

\subsection{Interaction pattern of Street-Level Bureaucracy In Implementation of Food Diversification Policy in Bone Regency}

Interaction patterns can be assessed in various ways such as considering the intensity of the interaction and to determine which actors are most closely related to each other. The results showed that the interaction pattern that was built between the Food Security Service and the Agriculture Office was an interaction pattern based on bureaucratic rules. The two institutions identified as street-level bureaucracy in this study each have different authorities on food availability so that the programs for this are also different. The Food Security Service has the authority to maintain the availability, accessibility, and balance of sustainable food consumption through food diversification policies. This policy is a hierarchical policy, in which the local government through the lower-level bureaucracy has a strategic position to realize the policy objectives.

The pattern of interaction between them is formed through food diversification programs designed in a topdown approach, such as the accelerated food consumption diversification program (P2KP), land food gardens (P2L) as a substitute for the sustainable food house program (RPL), and one-day programs. no rice. Based on this, the pattern of interaction is dominated by bureaucracy through street-level bureaucracy, because the provision of resources is all from the government (central government). Local bureaucratic governance has not provided a mechanism that encourages them to exercise discretion. This discretionary mechanism provides sufficient authority and space to develop their potential and interact with stakeholders. This mechanism also allows building synergy with other stakeholders.

\section{CONCLUSIONS}

Local bureaucratic governance is a mechanism that allows the street-level bureaucracy to exercise discretion in the implementation of food diversification policies. In order for this discretion to run effectively, it is necessary to strengthen institutions which include: patterns of perception, rules, and patterns of interaction. The different perceptual patterns of street-level bureaucracy in the implementation of food diversification policies make it difficult for them to make discretion to build a collaborative food diversification program. The rules that are formed in the interaction between actors are formal rules that have been designed top-down so that it is difficult for them to exercise discretion to improve the performance of this policy. The interaction pattern that is built in the implementation of this policy is the interaction pattern that is dominated by bureaucracy, street-level bureaucracy so that they do not allow discretion in this matter. Therefore, it is necessary to build a discretionary mechanism in local bureaucratic governance that has sufficient authority and space for them to interact and build collaborative programs.

\section{REFERENCES}

[1] Alwi. Susanti Gita. Rukmana Novayanti, "Going Local For Food Security: Strengthening Local Collaborative Institution In Implementation Of Food Security In Indonesia,” Int. J. Manag., vol. 11, no. 8, pp. 1998-2009.

[2] S. Goldsmith and W. D. Eggers, Governing by network: The new shape of the public sector. Washington DC: Brookings institution press, 2005.

[3] M. L. Goggin, Implementation theory and practice: Toward a third generation. Scott Foresman \& Co, 1990.

[4] M. Lipsky, Street-level bureaucracy: Dilemmas of the individual in public service. Russell Sage Foundation, 2010.

[5] E. H. Klijn and J. Koppenjan, Governance networks in the public sector. Routledge, 2015.

[6] W. R. Scott, Institutions and organizations: Ideas, interests, and identities. Sage publications, 2013.

[7] C. J. Koliba, J. W. Meek, A. Zia, and R. W. Mills, Governance networks in public 
administration and public policy. Routledge, 2018.

[8] K. P. Indonesia, "laporan Tahunan Badan Ketahanan Pangan," 2019.

[9] A. Alwi, A. Aslinda, and G. Susanti, "CrossSector Collaboration and Public Policy Accountability: Implementation Network of Food Security Policy in Bone Regency," in Iapa Proceedings Conference, 2019, pp. 88-102.

[10] A. Alwi and G. Susanti, "Food Security Policy
Implementation Network in Bone," Int. J. Multicult. Multireligious Underst., vol. 7, no. 1, pp. 734-741, 2020.

[11] A. Alwi and G. Susanti, "Complexity and Public Policy: Network Model of Food Security Policy Implementation in Bone Regency," in Iapa Proceedings Conference, 2019, pp. 522-533.

[12] R. K. Yin, Case study research and applications: Design and methods. Sage publications, 2017. 